\title{
Nutritional and safety evaluation of various liquid and powdered tea whiteners available in Pakistan
}

\author{
Muhammad SOHAIB ${ }^{1 \star}$ (D), Muhammad NAEEM ${ }^{1}$, Ahmad ALI ${ }^{1}$, Sanaullah IQBAL ${ }^{1}$, Adnan AMJAD ${ }^{2}$, \\ Kashif NAUMAN ${ }^{3}$ Shahzad AHMAD ${ }^{1}$, Mohsin RAZA ${ }^{1}$, Muhammad SAAD BIN JUNAID ${ }^{1}$, \\ Muhammad UMAIR RIAZ ${ }^{1}$
}

\begin{abstract}
The present study conducted to assess nutritional, safety parameters (aflatoxin $\mathrm{M}_{1} / \mathrm{AFM}_{1}$ and heavy metals; copper, cadmium and zinc) and fatty-acid composition of tea-whiteners (TWs). Accordingly, TW's samples composition (moisture, ash, protein, fat and nitrogen free extract) determined using AOAC methods, minerals including $\mathrm{Na}, \mathrm{K}$ and $\mathrm{Ca}$ heavy metals including $\mathrm{Cu}$, $\mathrm{Cd}$ and $\mathrm{Zn}$ determined via atomic absorption spectrophotometer. The $\mathrm{AFM}_{1}$ measured using thin layer chromatography (TLC) whereas, fatty acids and trans-fat contents were determined using gas chromatography. ANOVA and independent sample $t$ test applied to assess the significant difference. Results indicated that protein and fat contents (\%) of liquid TWs were 2.7-5.4 and 4.28-6.48, respectively. Powdered TWs protein and fat (\%) were 13.4-17, and 23.06-29.03, respectively. AFM was not found in any TW. $\mathrm{Cu} / \mathrm{Cd}$ and $\mathrm{Zn}$ levels (ppm) of liquid TWs were 0.296-2.075, ND-1.206 and 0.009-0.026 respectively. For powdered TWs the readings (ppm) were 0.515-0.632, 0.003-0.005 and 0.010-0.013 respectively. Trans-fats (\%) in liquid TWs were 2.90-7.51 and in powdered TWs were 1.29-1.83. In nutshell, TWs had traces of trans fats ranged 1.29-7.51\% whereas, liquid TWs contain more trans-fats than powdered TWs. Major fatty acids among liquid and powdered TWs were palmitic acid, heptadecanoic acid, stearic acid and oleic acid.
\end{abstract}

Keywords: tea whiteners; safety evaluation; trans-fat; heavy metals; aflatoxin.

Practical Application: Nutritional and safety evaluation of safety evaluation tea whiteners so that it can be used for its product regulation and consumer awareness.

\section{Introduction}

Tea-whiteners also known as non-dairy tea whiteners/ creamers having homologous functionality and characteristics compared to dairy products. They are specifically used for various hot cold beverages i.e., tea, coffee and cocoa etc. Typically, tea-whiteners are composed of vegetable fats, protein (sodium caseinate/ soy protein isolate), carbohydrates (sugar, maltodextrin or corn syrup) along with emulsifiers, stabilizers and other food additives. To replicate the mouth feel of dairy source the vegetable fats used in these whiteners may comprise of partially/ fully hydrogenated vegetable fats, palm oil, palm kernel oil, corn oil, cottonseed oil, sunflower oil and various blends of these aforementioned oils (Sher et al., 2013). Mocha Mix was the first ever non-dairy tea whitener of the world launched by Presto Food industry, California back in 1950's. Afterwards "Mocha Mate", Coffee Rich and Silk Soymilk creamers were developed in 1956, 1961 and 1999 respectively. The need of developing a dairy like product with extended shelf life came during the World War-II due to the shortage of the dairy products, so that the armed forces can use these products for longer periods and these products were economical as compared to the dairy products. So, at that time these non-dairy products made especial paces in market and they were available on almost every coffee vending machines (Shurtleff \& Aoyagi, 2013).

Second to water, tea and coffee are the most widely consumed beverages around the world. These beverages can be consumed with or without adding dairy as well as non-dairy tea whiteners. In Pakistan, multiple non-dairy creamers/ whiteners are available in market. These whiteners are produced by multiple national and international companies. According to a report published by LP Information INC, whiteners market will reach the revenue of 6810 US $\$$ in 2023 from the 5620 US \$ market in 2017 and will reach 3.7 million tons of production by 2025 (Orbis Research, 2018). Usually, tea is prepared by mixing fluid component and powdered or liquid NDC along with heating. Liquid component is usually hot/ boiling water.

Coming towards the composition of the nondairy tea whiteners, fat content of powdered and liquid nondairy tea whitener is between $25-50 \%$ and $3-18 \%$ respectively. Protein contents of powdered and liquid non-dairy tea whitener are $3-12 \%$ and $1-3 \%$ respectively and carbohydrate contents are $35-65 \%$ and $2.5-6 \%$ respectively (Tonner, 1978). Compared to 
NDC's, buffalo milk contains $6.89 \%$ of fats and cow milk contain $3.75 \%$ of fats which is considerably lower than amount of fats available in NDC's. The Carbohydrate content of the milk is only 5.18\% (United States Department of Agriculture, 2018). Major fat component of the NDC (coffee whiteners) is saturated fat which is approximately $98.71 \%$ (Karabulut, 2007). But bovine milk contains a variety of fat including $67 \%$ saturated fat, $26 \%$ mono-unsaturated fatty acid and $2 \%$ poly-unsaturated fatty acid (United States Department of Agriculture, 2018).

According to the (Gardiner, 1997) nondairy tea whiteners contain $20-40 \%$ of fats, $10 \%$ proteins and $35-60 \%$ of carbohydrates. The fats used in the nondairy tea whiteners can be palm oil and palm keirin oil. The carbohydrates used are usually corn syrup solid. Both partial and fully hydrogenated fats can be used in the nondairy tea whiteners formation. The partial hydrogenation can lead to formation of trans fats up to 20-40\% (Kummerow, 2009). On the other hand, fully hydrogenated fats virtually contain no trans fats but it results in excessive saturated fats intake (May \& Nesaretnam, 2014). There is a significant evidence available in literature showing the association of saturated fats and risk of coronary heart diseases (Chowdhury et al., 2014).

The consumption of nondairy tea whitener in Pakistan has dramatically increased in last couple of years. Punjab Food Authority (PFA) is issuing warning and prohibition notices about Nondairy tea whitener production, sale and consumption due to their associated health consequences. Director General, PFA issued an order stating that, it is mandatory for nondairy tea whiteners producers to print the required text on $15 \%$ of the carton's whole area that "This is not milk" (Dawn, 2017).

The need to carry out these actions was that various researches have documented adverse effects of these tea-whiteners on infant health and growth as in Pakistan a lot of peoples are consuming these products as milk replacement due to lack of awareness/ nutrition knowledge deficit and excessive advertisement on the electronic media. Major food producers and food systems heavily focus on the food safety parameters including microbial safety, toxins safety, allergen safety and heavy metals but the processing \& ultra-processing of foods can lead to decrease in nutrient density and nutrient quality, which is mostly neglected by these food systems (Poti et al., 2017).

Information about food composition is necessary for the assessment of diet quality and the development and application of food-based dietary guidelines, providing a useful tool for the field of public health nutrition (Elmadfa \& Meyer, 2010). Nondairy tea whiteners being made from partial and fully hydrogenated fats, it is necessary to nutritionally profile these products in order to aware the general public about the type and proportion of ingredients i.e., carbohydrates, proteins, fats as well as trans fats in it.

No baseline scientific data or literature is available on the safety and nutritional evaluation of these tea-whiteners. Therefore, present study planned to evaluate nutritional composition, safety assessment of commercially available TWs in Pakistan. Accordingly, all available brands were subjected to composition analysis including (moisture, dry matter, ash, crude protein, crude fat and NFE), aflatoxin $\left(\mathrm{M}_{1}\right)$, Minerals $(\mathrm{Na}, \mathrm{K}$ and $\mathrm{Ca})$ and heavy metals $(\mathrm{Cu}, \mathrm{Cd}$ and $\mathrm{Zn})$.

\section{Materials and methods:}

\subsection{Sampling of nondairy tea whiteners}

For the study, the tea-whiteners were procured from local market of Lahore, Pakistan from different locations involving local shops, general stores and hyper-markets. Moreover, to include all the possible brands of nondairy tea whiteners in the study, the procurement of nondairy tea whiteners was performed in local market with at least triplicate samples for each brand of nondairy tea whitener.

\subsection{Nutrition composition of different commercial whiteners}

The proximate analysis of all collected TWs performed at the beginning. Moisture (\%) \& dry matter was analyzed using method no. 934.01 (Association of Official Analytical Chemists, 2006b). Crude protein was measure using method no. 984.13 (Association of Official Analytical Chemists, 2006b). Crude protein was measure using method no. 920.39 (Association of Official Analytical Chemists, 2006b). Crude fiber was analyzed through method no. 978.10 (Association of Official Analytical Chemists, 2006b). Ash (\%) was analyzed using method no. 942.05 (Association of Official Analytical Chemists, 2006b). Nitrogen free extract (NFE) was measured using method described in (Association of Official Analytical Chemists, 2006b).

\subsection{Mineral composition analysis}

The mineral content such as $\mathrm{Na}, \mathrm{K}$ and $\mathrm{Ca}$ were measured in each of available nondairy tea whitener using flame photometry and Atomic Absorption Spectrophotometer following the methods described in (Sikirić et al., 2003). For the analysis, $1 \mathrm{~g} /$ $\mathrm{mL}$ sample was taken in conical flask and digested with $7 \mathrm{~mL}$ nitric acid for $5 \mathrm{~min}$ and afterwards $3 \mathrm{~mL}$ hypo-chloric acid was added. After the crystal-clear appearance, the total volume was made up to $25 \mathrm{~mL}$. Afterwards the sample was analyzed using Atomic Absorption Spectrophotometer along with the standard solutions. The absorbance of the standard solution was plotted using graph and values of the different minerals were calculated (Sikirić et al., 2003).

\subsection{Heavy metals analysis of tea whiteners}

The heavy metals $(\mathrm{Cu}, \mathrm{Cd}$ and $\mathrm{Zn})$ were quantified among all available nondairy tea-whiteners following the instructions described in (Meshref et al., 2014). For which $2 \mathrm{~mL} / 2 \mathrm{~g}$ nondairy tea whitener sample was digested using mixture of nitric acid and perchloric acid $\left(\mathrm{HNO}_{3}: \mathrm{HClO}_{3}=4: 1 \mathrm{v} / \mathrm{v}\right)$ to obtain a transparent solution. Digested samples were subjected to heavy metals quantification analysis $(\mathrm{Cu}, \mathrm{Cd}$ and $\mathrm{Zn})$ using flame atomic absorption spectrophotometer (Thermo Solar M6 A.A. Spectrometer, Thermo Electron) at wavelengths of 324.8, 228.8 and 213.9. The detection limits for $\mathrm{Cu}, \mathrm{Cd}$ and $\mathrm{Zn}$ were $0.001,0.005$ and $0.025 \mathrm{ppm}$ respectively. Blank as well as standard solutions of desired concentration were prepared 
using analytical grade chemicals and ultra-high purity water (Meshref et al., 2014).

\subsection{Aflatoxin assessment}

The qualitative estimation of Aflatoxins $M_{1}\left(\mathrm{AFM}_{1}\right)$ was performed for the commercial TWs using thin layer chromatography (TLC) by following the method described in (Bakirci, 2001). Silica gel 60 (Merch, dimensions $20 \times 20 \mathrm{~cm}^{2}$, thickness $0.2 \mathrm{~mm}$ ) and ultraviolet lamp (fisher UV lamp; $364^{\circ} \mathrm{C}$ ) were used for analysis. Total concentrations of primary $(1 \mathrm{ug} / \mathrm{mL})$ and working solutions $(0.5 \mathrm{ug} / \mathrm{mL})$ were prepared in chloroform solution for $\mathrm{AFM}_{1}$ standard and stored at dark place on room temperature. Extraction of AFM from non-dairy tea whitener samples was performed using chloroform and the extract was evaporated to a known volume. Afterwards all the samples were subjected to two-dimensional TLC and the fluorescence was observed for the presence/ absence of $\mathrm{AFM}_{1}$ in samples compared to standard (Bakirci, 2001).

\subsection{Fatty acid and trans fats determination in tea whiteners}

The fatty acid profile and trans-fat level of the commercial nondairy tea whitener brands were determined using gas chromatography apparatus (GC-2010 plus; Shimadzu, Kyoto, Japan) with Teknokroma capillary column (TR-CN 100, $100 \mathrm{~m} \mathrm{x}$ $0.32 \mathrm{~mm}$ x $0.20 \mathrm{um}, 100 \%$ Biscyanopropyl polysiloxane, unbound phase) following guidelines described in (Rozema et al., 2008) using AOAC method 996.06. Retention time and peak areas were observed at the end and were interpreted using external standard fatty acid methyl esters (FAME Mix GLC-37, SigmaAldrich, Germany).

\subsection{Sample preparation}

\section{Fat extraction}

The liquid TWs were centrifuged at $4000 \mathrm{rpm}$ for 10 15 minutes and upper fat bead was collected. The extraction of fat from upper fat bead was performed using $n$-hexane and diethyl ether: ether (50:50) separately. Excessive solvent (n-hexane \& diethyl ether: ether) was evaporated using rotary evaporator RV 10 digital V. For solid tea-whiteners, fat extraction was performed using the method of acid hydrolysis (Method no. 922.06) by following the guidelines described in (Association of Official Analytical Chemists, 2006a).

\section{Esterification}

Afterwards $50 \mathrm{mg}$ of extracted fat sample was taken with $2 \mathrm{~mL}$ of boron trifluoride (13-15\% $\mathrm{BF}_{3}$; methanol complex solution) in an air tight test tube and placed in water bath (Memmert, WNB 45I, Germany) for 45 minutes at $90^{\circ} \mathrm{C}$ in absence of light.

\section{Sample preparation for gas chromatography}

After esterification of fat, samples were cooled at room temperature. These samples were mixed with $\mathrm{n}$-hexane $(5 \mathrm{~mL})$ and placed on vortex mixture (ZX3; VELP SCIENTIFICA) for 1-2 minutes. The supernatant was collected and filtered using simple filter paper. During filtration few pinches of sodium sulphate (anhydrous) were placed on filter paper. The samples were dehydrated to remove any possible moisture and reconstituted to make final concentration of $10 \mathrm{mg} / \mathrm{mL}$ using $\mathrm{n}$-hexane. Afterwards samples were passed through 0.45 -micron filter and subjected to gas chromatography apparatus for fatty acid profile analysis.

\section{Chromatographic conditions of gas chromatography apparatus}

Mobile phase: Nitrogen, Total flow rate: $65.9 \mathrm{~mL} /$ minute, Carrier gas pressure: $128.9 \mathrm{Kpa}$, Detector: Flame ionization detector (FID), Injection volume: $2 \mu \mathrm{L}$, Spitless injection unit (SPL) temperature: $250^{\circ} \mathrm{C}$, FID temperature: $250^{\circ} \mathrm{C}$.

Column specification: Fused silica column (capillary) (Teknokroma TR-CN 100, Barcelona, Spain, $100 \mathrm{~m} \times 0.25 \mathrm{~mm}$ of internal diameter, $0.20 \mu \mathrm{m}$ of film thickness)

Temperature Program: Initial temperature was $40^{\circ} \mathrm{C}$ for 1 minute followed by $10^{\circ} \mathrm{C} /$ minute increase in temperature up to $200{ }^{\circ} \mathrm{C}$ with 5 minutes stay at $200{ }^{\circ} \mathrm{C}$. Again $5{ }^{\circ} \mathrm{C} /$ minute increase in temperature up to $240{ }^{\circ} \mathrm{C}$ with 30 minutes stay at $250^{\circ} \mathrm{C}$.

\subsection{Statistical analysis}

All the data was entered and analyzed using SPSS version 25.0 and one-way analysis of variance (ANOVA) was applied to determine the significant difference between the nutritional and safety parameters of the nondairy tea whiteners. Duncan multiple range test (DMRt) was applied on significant parameters to assess the inter-group differences $(\mathrm{p}<0.05)$.

\section{Results and discussion}

Multinational food and beverage companies with huge concentrated market power are known as "Big Food Systems" (Brownell \& Warner, 2009). About 15\% of the food sales are controlled by only 10 food companies around the globe (Alexander et al., 2011). Around $3 / 4^{\text {th }}$ of food sales involves processed foods for which the big food systems hold $>3^{\text {rd }}$ of global market share (Alfranca et al., 2003). According to a study conducted to assess the health impact of big food systems stated that they are not meeting the dietary needs of the world (De Schutter, 2011), as they are not driven to deliver optimal diet but to maximize profits (Stuckler \& Nestle, 2012). Majority of sales of these food systems occur in developing countries (Hawkes, 2002) and global producers are the main reason for the transition of simple/ traditional diet to a highly processed diet (Hawkes, 2005; Popkin, 2002). These food systems are also considered as a driving force behind increased consumption of salt, sugar, fats which can be linked with increasing obesity and non-communicable diseases (NCDs) (Basu et al., 2013). TWs being processed foods are composed of sugars and vegetable fats (partial/completely hydrogenated) therefore their nutritional and safety parameters should be evaluated as these NDTWs are manufactured at huge scale with excessive market value.

Nondairy tea whiteners (NDTW) are the substitute of dairy products specifically used in preparation of hot and cold beverages i.e., tea, coffee and cocoa drinks. NDTWs are available 
in powdered and liquid forms. The present study was carried out with the aim to assess the nutrition composition, aflatoxin analysis, heavy metals detection and fatty acid profiling with specific focus on trans fats for various liquid and powdered NDTWs available in Pakistan. Table 1 elaborates the nutritional composition of multiple powdered and liquid nondairy tea whiteners. Protein contents of liquid and powdered TWs were in the range between $2.7-5.4 \%$ and $13.4-17 \%$ respectively. Fats contents of powdered and liquid TWs are within the range of 23.06-29.03\% and 4.28-6.48\% respectively. On the other hand, ash contents of liquid TWs were in the range of $0.22-0.85 \%$ and for powdered tea-whiteners ash contents were between 6.24-6.60\% (Table 1).

The fat and protein concentrations of UHT treated liquid TWs (5.90-6.0\% and 3.15-3.28\% respectively) were reported by (Ajmal et al., 2019). The findings were in lined with present study's fat concentrations for liquid TWs but the protein concentrations in liquid TWs were between the range of 2.7 to $5.4 \%$ with majority of the TWs having more than $4 \%$ protein concentrations (Table 1). The protein concentrations in present study were a higher than the above cited study findings (Ajmal et al., 2019).

Table 2 explains the mineral composition of various powdered and liquid TWs with respect to sodium, potassium and calcium levels. The level of $\mathrm{Na}$ found in liquid and powdered TWs was in the range between $15.06-36.06 \mathrm{mg} / \mathrm{L}$ and $24.00-$ $29.06 \mathrm{mg} / \mathrm{L}$ respectively. $\mathrm{K}$ and Ca contents of liquid TWs were in the range between $10.60-18.98 \mathrm{mg} / \mathrm{L}$ and $19.10-14.13 \mathrm{mg} / \mathrm{L}$ respectively. Potassium contents were for powdered TWs were between $13.25-14.03 \mathrm{mg} / \mathrm{L}$ and calcium contents were between $19.80-21.21 \mathrm{mg} / \mathrm{L}$ for powdered nondairy tea whiteners (Table 2).

All the powdered and liquid TWs were free from Aflatoxin $\mathrm{M}_{1}\left(\mathrm{AFM}_{1}\right)$ as nothing was determined using qualitative analysis of TWs for AFM 1 using TLC method. These results were again confirmed by high pressure liquid chromatography (HPLC). Table 3 elaborates the quantification of heavy metals among powdered and liquid TWs. The copper, cadmium and zinc levels of liquid nondairy tea whiteners were in the range between 0.296-2.075 ppm, ND-1.206 ppm and 0.009-0.026 ppm respectively. On the other $\mathrm{Cu}, \mathrm{Cd}$ and $\mathrm{Zn}$ levels of powdered TWs were in the range between 0.515-0.632 ppm, 0.003-0.005 ppm and $0.010-0.013 \mathrm{ppm}$ respectively (Table 3 ).
According to the European commission (EC) maximum residual limits (MRLs) for $\mathrm{AFM}_{1}$ in milk is $50 \mathrm{ng} / \mathrm{L}$ (European Commission, 2006) while according to legislative bodies of US, China and Brazil, it is $500 \mathrm{ng} / \mathrm{L}$. For milk-based food products MRL for $\mathrm{AFM}$ is $500 \mathrm{ng} / \mathrm{L}$ according to $\mathrm{EU}$ (European Commission, 2006). All the samples of TWs were within the recommendations of EU, FDA and other countries legislative bodies as nothing was determined by the TLC detection of $\mathrm{AFM}_{1}$ (Table 3). Which was later on also confirmed by HPLC analysis. There are no established maximum residual limits for $\mathrm{Cu}, \mathrm{Cd}$ and $\mathrm{Zn}$ available with respect to milk \& dairy products by Codex Alimentarius (Food and Agriculture Organization, 2012). But this data serves as baseline for heavy metal analysis in TWs and can be used for further analysis (Table 3).

$\mathrm{Tea} / \mathrm{coffee}$ are one of the mostly consumed beverages around the globe after water and use of coffee/tea-whitener is also among the frequently consumed snack. The fatty acid composition of these snacks should be estimated so that the nutritional values of these products can be calculated. In a study, fatty acid composition of coffee creamers (powdered) was estimate and results showed very minute quantities of trans fats $(0.34 \%)$ with $98.7 \%$ of saturated fats (Karabulut, 2007). In present study, trans fatty acid levels of powdered TWs were 1.2-1.8\% with saturated fats of about $36-51 \%$.

Results (Table 4) regarding fatty acid profile of various powdered and liquid nondairy tea whiteners. Overall, saturated fatty acid contents of various liquid TWs were between the range of $32.63-54.73 \%$. On the other hand, $44.21-58.13 \%$ of saturated fatty acid contents were found in powdered TWs. Unsaturated fatty acid contents of powdered and liquid TWs were in the range of $38.88-53.32 \%$ and $57.01-73.10 \%$ respectively. The total trans-fat contents found in powdered and liquid TWs were between 1.29-1.83\% and 2.90-7.51\% (excluding LTW7: 0.07\%). Liquid nondairy tea whiteners had more trans-fats compared to powdered nondairy tea whiteners. Palmitic acid, heptadecanoic acid, stearic acid and oleic acid were the most abundant fatty acids in liquid and powdered TWs. Lauric and myristic acid were abundantly incorporating in fatty acid profile of only powdered nondairy tea whiteners. Palmitic acid contents of powdered TWs were in the range of 9.77-27.77\% and for liquid NDTWs it was between 20.78-41.61\%. Heptadecanoic acid contents of powdered and liquid NDTWs were in the range of $21.21-40.55 \%$

Table 1. Proximate composition of multiple liquid and powdered tea-whiteners available in Pakistan.

\begin{tabular}{ccccccc}
\hline Tea whiteners & Moisture & Dry matter & Ash & Crude Protein & Crude Fat \\
\hline LTW1 & $85.50^{\mathrm{b}} \pm 0.20$ & $14.50^{\mathrm{cd}} \pm 0.25$ & $0.40^{\mathrm{c}} \pm 0.02$ & $4.23^{\mathrm{b}} \pm 0.15$ & $6.46^{\mathrm{a}} \pm 0.25$ & $3.41^{\mathrm{c}} \pm 0.35$ \\
LTW2 & $85.76^{\mathrm{a}} \pm 0.11$ & $14.24^{\mathrm{d}} \pm 0.20$ & $0.40^{\mathrm{c}} \pm 0.01$ & $2.83^{\mathrm{d}} \pm 0.30$ & $6.36^{\mathrm{a}} \pm 0.15$ & $4.65^{\mathrm{b}} \pm 0.15$ \\
LTW3 & $85.23^{\mathrm{c}} \pm 0.11$ & $14.77^{\mathrm{c}} \pm 0.15$ & $0.22^{\mathrm{e}} \pm 0.02$ & $3.43^{\mathrm{c}} \pm 0.20$ & $6.40^{\mathrm{a}} \pm 0.50$ & $4.72^{\mathrm{b}} \pm 0.25$ \\
LTW4 & $84.75^{\mathrm{d}} \pm 0.05$ & $15.25^{\mathrm{b}} \pm 0.15$ & $0.85^{\mathrm{a}} \pm 0.02$ & $5.40^{\mathrm{a}} \pm 0.30$ & $4.28^{\mathrm{c}} \pm 0.12$ & $4.72^{\mathrm{b}} \pm 0.12$ \\
LTW5 & $85.35^{\mathrm{bc}} \pm 0.13$ & $14.65^{\mathrm{c}} \pm 0.13$ & $0.28^{\mathrm{d}} \pm 0.01$ & $5.36^{\mathrm{a}} \pm 0.15$ & $5.75^{\mathrm{b}} \pm 0.13$ & $3.26^{\mathrm{c}} \pm 0.13$ \\
LTW6 & $84.90^{\mathrm{d}} \pm 0.10$ & $15.10^{\mathrm{b}} \pm 0.15$ & $0.28^{\mathrm{d}} \pm 0.02$ & $4.40^{\mathrm{b}} \pm 0.230$ & $5.70^{\mathrm{b}} \pm 0.20$ & $4.72^{\mathrm{b}} \pm 0.25$ \\
LTW7 & $84.18^{\mathrm{e}} \pm 0.10$ & $15.82^{\mathrm{a}} \pm 0.12$ & $0.60^{\mathrm{b}} \pm 0.02$ & $2.70^{\mathrm{d}} \pm 0.17$ & $6.48^{\mathrm{a}} \pm 0.12$ & $6.04^{\mathrm{a}} \pm 0.12$ \\
PTW1 & $2.20^{\mathrm{b}} \pm 0.20$ & $97.80 \pm 6.40$ & $6.24^{\mathrm{b}} \pm 0.05$ & $17.00^{\mathrm{a}} \pm 0.30$ & $29.03^{\mathrm{a}} \pm 0.15$ & $52.27^{\mathrm{a}} \pm 0.27$ \\
PTW2 & $2.76^{\mathrm{a}} \pm 0.15$ & $97.24 \pm 4.28$ & $6.60^{\mathrm{a}} \pm 0.02$ & $13.40^{\mathrm{b}} \pm 0.17$ & $23.06^{\mathrm{b}} \pm 0.11$ & $43.06^{\mathrm{b}} \pm 0.16$ \\
\hline
\end{tabular}

Data presented as mean \pm SD; NFE = nitrogen free extract; LTW = liquid tea whitener; PTW = powdered tea whitener. For liquid tea-whiteners (one-way ANOVA) and for powdered tea-whiteners (independent sample $t$ test) was applied. Superscripts in each column are representing significant different groups separately for liquid and powdered tea-whiteners, wet and dry basis calculations were performed for liquid and powdered TWs respectively. 
Table 2. Mineral analysis of multiple liquid and powdered tea-whiteners available in Pakistan.

\begin{tabular}{cccc}
\hline Tea whiteners & $\mathrm{Na}(\mathrm{mg} / \mathrm{L})$ & $\mathrm{K}(\mathrm{mg} / \mathrm{L})$ & $\mathrm{Ca}(\mathrm{mg} / \mathrm{L})$ \\
\hline LTW1 & $19.00^{\mathrm{d}} \pm 0.30$ & $11.95^{\mathrm{b}} \pm 0.18$ & $15.03^{\mathrm{c}} \pm 0.15$ \\
LTW2 & $29.93^{\mathrm{b}} \pm 0.25$ & $14.58^{\mathrm{b}} \pm 0.20$ & $19.28^{\mathrm{b}} \pm 0.10$ \\
LTW3 & $15.06^{\mathrm{d}} \pm 0.20$ & $11.01^{\mathrm{c}} \pm 0.23$ & $14.13^{\mathrm{c}} \pm 0.11$ \\
LTW4 & $23.46^{\mathrm{c}} \pm 0.15$ & $18.98^{\mathrm{a}} \pm 0.24$ & $21.35^{\mathrm{a}} \pm 0.13$ \\
LTW5 & $15.76^{\mathrm{d}} \pm 0.11$ & $10.60^{\mathrm{c}} \pm 0.35$ & $13.50^{\mathrm{d}} \pm 0.20$ \\
LTW6 & $19.90^{\mathrm{d}} \pm 0.30$ & $14.61^{\mathrm{b}} \pm 0.23$ & $19.10^{\mathrm{b}} \pm 0.10$ \\
LTW7 & $36.06^{\mathrm{a}} \pm 0.20$ & $16.35^{\mathrm{a}} \pm 0.27$ & $19.48^{\mathrm{b}} \pm 0.17$ \\
PTW1 & $29.06^{\mathrm{b}} \pm 0.30$ & $13.25^{\mathrm{b}} \pm 0.13$ & $21.21^{\mathrm{a}} \pm 0.20$ \\
PTW2 & $24.00^{\mathrm{c}} \pm 0.17$ & $14.03^{\mathrm{b}} \pm 0.25$ & $19.80^{\mathrm{b}} \pm 0.26$ \\
\hline
\end{tabular}

Data presented as mean \pm SD; LTW $=$ liquid tea whitener; PTW = powdered tea whitener. Different superscripts in a column are representing significantly different groups.

Table 3. Heavy metals and aflatoxin $\mathrm{M}_{1}\left(\mathrm{AFM}_{1}\right)$ estimation of multiple liquid and powdered tea-whiteners available in Pakistan add limits for EU and Codex for heavy metals in this table for comparison.

\begin{tabular}{ccccc}
\hline $\begin{array}{c}\text { Tea } \\
\text { whiteners }\end{array}$ & $\mathrm{Cu}(\mathrm{ppm})$ & $\mathrm{Cd}(\mathrm{ppm})$ & $\mathrm{Zn}(\mathrm{ppm})$ & $\mathrm{AFM}_{1}$ \\
\hline LTW1 & 0.388 & $\mathrm{ND}$ & 0.012 & $\mathrm{ND}$ \\
LTW2 & 2.075 & 1.206 & 0.026 & $\mathrm{ND}$ \\
LTW3 & 0.717 & 0.006 & 0.015 & $\mathrm{ND}$ \\
LTW4 & 1.064 & $\mathrm{ND}$ & 0.015 & $\mathrm{ND}$ \\
LTW5 & 0.375 & $\mathrm{ND}$ & 0.016 & $\mathrm{ND}$ \\
LTW6 & 0.296 & $\mathrm{ND}$ & 0.011 & $\mathrm{ND}$ \\
LTW7 & 0.563 & $\mathrm{ND}$ & 0.009 & $\mathrm{ND}$ \\
PTW1 & 0.515 & 0.005 & 0.013 & $\mathrm{ND}$ \\
PTW2 & 0.632 & 0.003 & 0.010 & $\mathrm{ND}$ \\
\hline
\end{tabular}

ND: Not Determined; $\mathrm{ppm}=$ parts per million; LTW = liquid tea whitener; PTW $=$ powdered tea whitener. (excluding LTW6: 0.10\%) and 24.44-40.19\% respectively. Stearic acid contents for liquid and powdered TWs were in the range between $4.67-12.88 \%$ and $8.26-23.0 \%$ respectively. Oleic acid contents of liquid TWs were in the range of 14.41-28.75\% (Table 4).

The saturated fatty acid levels of powdered and liquid TWs were in the range of $30.4-72.3 \%$ and $49-63.9 \%$ respectively. Un-saturated fats in liquid TWs were between the range of 27.65 to $69.6 \%$ and in powdered nondairy tea whiteners, these concentrations were 36 to $50.9 \%$. A study conducted to assess the fatty acid composition of various UHT treated products (nondairy tea-whiteners/ milk/ dairy drinks) reported a trans fatty acid $\left(\mathrm{C}_{18: 1}\right)$ concentration of $18.1-18.5 \%$ among the liquid nondairy tea whiteners. Our study findings reported a lesser concentration of trans fats ranging between 3-5\% of trans fats for majority of liquid TWs with an exception of $7.51 \%$ and $0.08 \%$ trans fats. One thing that needs to be noted that present study has quantified the fatty acid composition of TWs without any high temperature treatment e.g., UHT. But still considerable proportions of trans fats were found in liquid TWs (3-5\%) (Ajmal et al., 2019).

Liquid nondairy tea whiteners contain partially hydrogenated fats and most of the oil processor perform hydrogenation because it provides oxidative stability to the final product as it increases the saturation of the product (Timmons et al., 2001) as confirmed by the (Ajmal et al., 2019) that liquid nondairy tea whiteners contain $18 \%$ trans fats which are dangerously higher than normal. On the other hand, fats used in powdered tea whiteners are fully hydrogenated vegetable fat which contain virtually no trans fats and these findings were confirmed by (Suwannakood et al., 2012) with trans fats level of $0.1-0.4 \%$ only.

The trans-fat contents (\%) of goat, sheep and cow's milk are $0.45,0.76$ and 0.57 respectively (Markiewicz-Kęszycka et al.,

Table 4. Fatty acid profile of multiple liquid and powdered tea-whiteners available in Pakistan.

\begin{tabular}{|c|c|c|c|c|c|c|c|c|c|c|c|c|}
\hline \multirow{2}{*}{ No } & \multicolumn{2}{|c|}{ Fatty acids } & \multicolumn{7}{|c|}{ Liquid Tea Whiteners (\%) } & \multicolumn{3}{|c|}{ Powdered Tea Whiteners (\%) } \\
\hline & Name & Formula & LTW1 & LTW2 & LTW3 & LTW4 & LTW5 & LTW6 & LTW7 & PTW1 & PTW2 & PTW3 \\
\hline 1 & Lauric & $\mathrm{C} 12: 0$ & - & 0.20 & 0.23 & 0.20 & - & 0.26 & 0.22 & 0.37 & 8.98 & 8.81 \\
\hline 2 & Myristic & C14:0 & 0.35 & 0.66 & 0.77 & 0.71 & 0.35 & 1.01 & 0.36 & 7.81 & 11.88 & 13.93 \\
\hline 3 & Palmitic & $\mathrm{C} 16: 0$ & 25.58 & 26.75 & 29.04 & 29.36 & 20.78 & 41.61 & 23.69 & 27.77 & 9.77 & 12.39 \\
\hline 4 & Palmitoleic & C16:1 & 9.50 & 3.60 & 3.81 & 2.87 & 3.51 & 0.15 & 12.94 & 2.39 & 3.04 & 2.84 \\
\hline 5 & Heptadecanoic & $\mathrm{C} 17: 1$ & 27.69 & 32.81 & 26.74 & 24.44 & 40.19 & 0.10 & 27.37 & 21.21 & 40.55 & 28.99 \\
\hline 6 & Stearic & C18:0 & 12.88 & 6.49 & 10.38 & 7.44 & 4.67 & 11.77 & 8.36 & 8.26 & 16.80 & 23.00 \\
\hline 7 & Elaidic (trans) & C18:1 & 5.55 & 3.11 & 5.29 & 2.90 & 4.96 & 7.41 & 0.07 & 1.83 & 1.29 & 1.31 \\
\hline 8 & Oleic (cis) & C18:1 & 14.41 & 20.57 & 17.28 & 23.68 & 20.03 & 28.75 & 20.58 & 23.01 & 2.09 & 2.54 \\
\hline 9 & Linoelaidic (trans) & $\mathrm{C} 18: 2$ & - & - & - & - & 0.05 & 0.10 & - & - & - & - \\
\hline 10 & Linoleic (cis) & C18:3 & 2.83 & 4.84 & 3.60 & 5.69 & 4.12 & 6.25 & 5.67 & 4.19 & 2.02 & 2.76 \\
\hline 11 & $\gamma$-Linolenic $\left(\gamma^{6}\right)$ & $\mathrm{C} 18: 3$ & 0.29 & 0.20 & 0.23 & 0.22 & 0.24 & 0.32 & 0.26 & 0.23 & 0.18 & 0.25 \\
\hline 12 & $\alpha$-Linolenic $(\gamma 3)$ & $\mathrm{C} 18: 3$ & - & - & - & 0.09 & - & - & - & - & - & - \\
\hline 13 & Arachidic & C20:0 & - & 0.07 & - & 0.08 & 0.08 & 0.08 & - & - & 0.02 & - \\
\hline 14 & Eicosanoic & C20:1 & - & 0.08 & 0.06 & 0.11 & - & 0.12 & - & 0.46 & 0.15 & 0.19 \\
\hline \multicolumn{3}{|c|}{ Total } & 99.07 & 99.39 & 97.43 & 97.78 & 99.00 & 97.92 & 99.51 & 97.52 & 96.77 & 97.01 \\
\hline \multicolumn{3}{|c|}{ Saturated fatty acids } & 38.81 & 34.17 & 40.42 & 37.79 & 25.88 & 54.73 & 32.63 & 44.21 & 47.45 & 58.13 \\
\hline \multicolumn{3}{|c|}{ Unsaturated fatty acids } & 60.27 & 65.21 & 57.01 & 60.00 & 73.10 & 43.20 & 66.89 & 53.32 & 49.32 & 38.88 \\
\hline \multicolumn{3}{|c|}{ Total trans fats } & 5.55 & 3.11 & 5.29 & 2.90 & 5.01 & 7.51 & 0.07 & 1.83 & 1.29 & 1.31 \\
\hline
\end{tabular}

LTW = liquid tea whitener; PTW = powdered tea whitener. 
2013). Compared to dairy milk from various milk species, trans-fats were significantly higher in both liquid and powdered TWs (majority 3-5\%). Dairy milk from different species contains variety of fatty acids which were absent in these TWs as these TWs majorly consists of palmitic acid, stearic acid, oleic acid and heptadecanoic acid (Table 4). Increased concentrations of myristic, palmitic and stearic acid is known to be associated with type 2 diabetes and other non-communicable diseases (NCDs) (Calder, 2015). Therefore, these products should be treated differently from milk products because they are only designed for tea and coffee preparation. The health care providers and dietitian should educate general population on safe use of these products and so that these products may not be used as dairy products. Keeping in view the findings of the latest researches FDA in 2015 issued the order to ban the major source of artificial source of trans fats in diet which is the partial hydrogenated fats (Grossman, 2015).

\section{Conclusion}

Present study reported that proximate analysis of powdered tea-whiteners suggested fat contents of $23-29 \%$, and protein contents of 13.4-17\%. Protein and fat contents (\%) of liquid teawhiteners were 2.7-5.4 and 4.2-6.4 respectively. Sodium, potassium and calcium contents $(\mathrm{mg} / \mathrm{L}$ ) of tea-whiteners were between the range of 15.76-36.06, 10.6-18.9 and 15.03-21.35 respectively. Heavy metals $(\mathrm{Cu}, \mathrm{Cd}$ ad $\mathrm{Zn})$ were between the range of $0.388-2.075,0.003-1.206$ and $0.009-0.026$ ppm respectively. All the tea-whiteners were free from Aflatoxin $M_{1}$. Trans fatty acid contents were between the range of $0.087-7.51 \%$ in liquid TWs and $1.287-1.831 \%$ in powdered tea-whiteners. Major fatty acids observed in fatty acid analysis of powdered/liquid TWs were palmitic acid, heptadecanoic acid, stearic acid, and oleic acid. The lower- and middle-income countries should strictly follow guidelines suggested by FDA with respect to immitant dairy products and food industries should focus on developing low fat, low calories nondairy tea whiteners with least if possible zero levels of trans fats along with proper labeling of nutritional facts.

\section{Acknowledgements}

The study was funded by the Higher Education Commission Pakistan under (NRPU; National Research Program for Universities) Project titled "Nutritional profiling, Safety assessment and Bio-evaluation of commercial tea whiteners available in Pakistan" with project No.7190/Punjab/ NRPU/R\&D/HEC/ 2017.

\section{References}

Ajmal, M., Nadeem, M., Imran, M., Mushtaq, Z., Ahmad, M. H., Tayyab, M., Khan, M. K., \& Gulzar, N. (2019). Changes in fatty acids composition, antioxidant potential and induction period of UHT-treated tea whitener, milk and dairy drink. Lipids in Health and Disease, 18(1), 213. http://dx.doi.org/10.1186/s12944-0191161-x. PMid:31810485.

Alexander, E., Yach, D., \& Mensah, G. A. (2011). Major multinational food and beverage companies and informal sector contributions to global food consumption: implications for nutrition policy. Globalization and Health, 7(1), 26. http://dx.doi.org/10.1186/17448603-7-26. PMid:21806827.
Alfranca, O., Rama, R., \& Von Tunzelmann, N. (2003). Technological fields and concentration of innovation among food and beverage multinationals. International Food and Agribusiness Management Review, 5(2), 1-14.

Association of Official Analytical Chemists - AOAC. (2006a). Fat extraction and determination by acid hydrolysis. Retrieved from http://www.eoma.aoac.org/methods/info.asp?ID=26940

Association of Official Analytical Chemists - AOAC. (2006b). Official Methods of Analysis of AOAC International (17th ed.). Arlington: AOAC. Retrieved from https://books.google.com.pk/ books?id=rrEmAAAACAAJ

Bakirci, I. (2001). A study on the occurrence of aflatoxin M1 in milk and milk products produced in Van province of Turkey. Food Control, 12(1), 47-51. http://dx.doi.org/10.1016/S0956-7135(00)00020-7.

Basu, S., Stuckler, D., McKee, M., \& Galea, G. (2013). Nutritional determinants of worldwide diabetes: an econometric study of food markets and diabetes prevalence in 173 countries. Public Health Nutrition, 16(1), 179-186. http://dx.doi.org/10.1017/ S1368980012002881. PMid:22691632.

Brownell, K. D., \& Warner, K. E. (2009). The perils of ignoring history: Big Tobacco played dirty and millions died. How similar is Big Food? The Milbank Quarterly, 87(1), 259-294. http://dx.doi. org/10.1111/j.1468-0009.2009.00555.x. PMid:19298423.

Calder, P. C. (2015). Functional roles of fatty acids and their effects on human health. Journal of Parenteral and Enteral Nutrition, 39(Suppl. 1), 18S-32S. http://dx.doi.org/10.1177/0148607115595980. PMid:26177664.

Chowdhury, R., Warnakula, S., Kunutsor, S., Crowe, F., Ward, H. A., Johnson, L., Franco, O. H., Butterworth, A. S., Forouhi, N. G., Thompson, S. G., Khaw, K. T., Mozaffarian, D., Danesh, J., \& Di Angelantonio, E. (2014). Association of dietary, circulating, and supplement fatty acids with coronary risk: a systematic review and meta-analysis. Annals of Internal Medicine, 160(6), 398-406. http:// dx.doi.org/10.7326/M13-1788. PMid:24723079.

Dawn. (2017). PFA approves new tea whitener packaging. Dawn. Retrieved from https://www.dawn.com/news/1325631

Elmadfa, I., \& Meyer, A. L. (2010). Importance of food composition data to nutrition and public health. European Journal of Clinical Nutrition, 64(Suppl. 3), S4-S7. http://dx.doi.org/10.1038/ejcn.2010.202. PMid:21045848.

European Commission. (2006). Commission Regulation (EC) No 1881/2006 of 19 December 2006 setting maximum levels for certain contaminants in foodstuffs. The Official Journal of the European Union, p. 365-324.

Food and Agriculture Organization - FAO. World Health Organization - WHO. (2012). Joint FAO/WHO food standards program: Codex committee on contaminants in foods (Editorial amendments to the general standard for contaminants and toxins in food and feed). Rome: FAO.

Gardiner, D. S. (1997). U.S. Patent No. US4046926A. Washington, DC: U.S. Patent and Trademark Office.

Grossman, M. R. (2015). FDA issues order to ban artificial trans fat by 2018. European Food and Feed Law Review, 10, 317.

Hawkes, C. (2002). Marketing activities of global soft drink and fast food companies in emerging markets, a review. In WHO (Org.), Globalization, Diets and Noncommunicable Diseases. Geneva: WHO.

Hawkes, C. (2005). The role of foreign direct investment in the nutrition transition. Public Health Nutrition, 8(4), 357-365. http://dx.doi. org/10.1079/PHN2004706. PMid:15975180. 
Karabulut, I. (2007). Fatty acid composition of frequently consumed foods in Turkey with special emphasis on trans fatty acids. International Journal of Food Sciences and Nutrition, 58(8), 619-628. http://dx.doi. org/10.1080/09637480701368967. PMid:17852509.

Kummerow, F. A. (2009). The negative effects of hydrogenated trans fats and what to do about them. Atherosclerosis, 205(2), 458-465. http:// dx.doi.org/10.1016/j.atherosclerosis.2009.03.009. PMid:19345947.

Markiewicz-Kęszycka, M., Czyżak-Runowska, G., Lipińska, P., \& Wójtowski, J. (2013). Fatty acid profile of milk-a review. Bulletin of the Veterinary Institute in Pulawy, 57(2), 135-139. http://dx.doi. org/10.2478/bvip-2013-0026.

May, C. Y., \& Nesaretnam, K. (2014). Research advancements in palm oil nutrition. European Journal of Lipid Science and Technology, 116(10), 1301-1315. http://dx.doi.org/10.1002/ejlt.201400076. PMid:25821404.

Meshref, A. M., Moselhy, W. A., \& Hassan, N. E. Y. (2014). Heavy metals and trace elements levels in milk and milk products. Journal of Food Measurement and Characterization, 8(4), 381-388. http:// dx.doi.org/10.1007/s11694-014-9203-6.

Orbis Research. (2018). Global non-dairy creamer sales market 2018 industry trend and forecast 2025. Maharashtra: Orbis Research. Retrieved from https://orbisresearch.com/reports/index/global-nondairy-creamer-sales-market-2018-industry-trend-and-forecast-2025

Popkin, B. M. (2002). Part II. What is unique about the experience in lower-and middle-income less-industrialised countries compared with the very-highincome industrialised countries? Public Health Nutrition, 5(1a), 205-214. http://dx.doi.org/10.1079/PHN2001295. PMid:12027286.

Poti, J. M., Braga, B., \& Qin, B. (2017). Ultra-processed food intake and obesity: what really matters for health-processing or nutrient content? Current Obesity Reports, 6(4), 420-431. http://dx.doi. org/10.1007/s13679-017-0285-4. PMid:29071481.

Rozema, B., Mitchell, B., Winters, D., Kohn, A., Sullivan, D., \& Meinholz, E. (2008). Proposed modifications to AOAC 996.06, optimizing the determination of trans fatty acids: presentation of data. Journal of AOAC International, 91(1), 92-97. http://dx.doi.org/10.1093/ jaoac/91.1.92. PMid:18376590.

Schutter, O. (2011). Report submitted by the Special Rapporteur on the right to food. Retrieved from https://www.ohchr.org/en/issues/food/ pages/foodindex.aspx

Sher, A. A., Beeson, C. A., Octavia, W., \& Gutierrez, J. A. (2013). U.S. Patent No. US20130122178A1. Washington, DC: U.S. Patent and Trademark Office.

Shurtleff, W., \& Aoyagi, A. (2013). History of soymilk and other nondairy milks (1226-2013). Lafayette: Soyinfo Center.

Sikirić, M., Brajenović, N., Pavlović, I., Havranek, J., \& Plavljanić, N. (2003). Determination of metals in cow's milk by flame atomic absorption spectrophotometry. Czech Journal of Animal Science, 48(11), 481-486.

Stuckler, D., \& Nestle, M. (2012). Big food, food systems, and global health. PLoS Medicine, 9(6), e1001242. http://dx.doi.org/10.1371/ journal.pmed.1001242. PMid:22723746.

Suwannakood, W., Patarapanich, C., \& Tongyonk, L. (2012). Analysis of trans fatty acid content in snacks and non-dairy creamers by Attenuated Total Reflection Fourier Transform Infrared spectroscopy. Journal of Health Research, 26(1), 35-39.

Timmons, J., Weiss, W., Palmquist, D., \& Harper, W. (2001). Relationships among dietary roasted soybeans, milk components, and spontaneous oxidized flavor of milk. Journal of Dairy Science, 84(11), 2440-2449. http://dx.doi.org/10.3168/jds.S0022-0302(01)74694-2. PMid:11768085.

Tonner, G. F. (1978).. (2013). U.S. Patent No. US4092438A. Washington, DC: U.S. Patent and Trademark Office.

United States Department of Agriculture - USDA. (2018). National nutrient database for standard reference; full report (all nutrients) 01108, milk, indian buffalo, fluid. Retrieved from https://ndb.nal. usda.gov/ndb/foods/show $/ 01108$ ?fgcd=\&manu=\&format=\&count $=\& \max =25 \&$ offset $=\&$ sort $=$ default\&order $=$ asc \&qlookup $=$ indian $+b$ uffalo + milk $\& d s=\& q \mathrm{t}=\& q \mathrm{p}=\& \mathrm{qa}=\& \mathrm{qn}=\& \mathrm{q}=\&$ ing $=$ 